Research Report No. 26/2008

\title{
The Ties that Bind: Indigenous Peoples and Environmental Governance
}

Benjamin J. Richardson

Osgoode Hall Law School of York University

Follow this and additional works at: http:// digitalcommons.osgoode.yorku.ca/clpe

\section{Recommended Citation}

Richardson, Benjamin J., "The Ties that Bind: Indigenous Peoples and Environmental Governance" (2008). Comparative Research in Law \& Political Economy. Research Paper No. 26/2008.

http://digitalcommons.osgoode.yorku.ca/clpe/197 


\section{Comparative Research in Law \& Political Economy}

Benjamin J . Richardson

The Ties That Bind: Indigenous Peoples and Environmental Governance

Forthcoming in Indigenous Peoples and the Law: Comparative and Critical Perspectives (Oxford: Hart Publishing, 2009)

EDITORS: Peer Zumbansen (Osgoode Hall Law School, Toronto, Director, Comparative Research in Law and Political Economy, York University), J ohn W. Cioffi (University of California at Riverside), Lindsay Krauss (Osgoode Hall Law School, Toronto, Production Editor) 

CLPE Research Paper 26/2008

Vol. 04 No. 05 (2008)

\title{
Benjamin J. Richardson
}

\section{The TIES THAT BIND: INDIGENOUS PEOPLES AND ENVIRONMENTAL GOVERNANCE}

\begin{abstract}
Canvassing practices in many countries, this chapter analyses the relationships between Indigenous peoples and environmental governance. It examines the environmental values and practices of Indigenous peoples, primarily in order to assess their implications for the Indigenous stake in environmental governance. It identifies at least six major theories or perspectives concerning Indigenous environmental values and practices. Secondly, the chapter reviews the legal norms and governance tools that structure Indigenous involvement in environmental management, in order to assess their relative value for Indigenous stakeholders and implications for sustainable utilisation of natural resources.
\end{abstract}

Keywords: Environmental law, Indigenous peoples, Indigenous resource rights, legal pluralism, traditional environmental knowledge.

JEL classification: K39

\author{
Author Contact: \\ Benjamin J. Richardson \\ Professor, Osgoode Hall Law School, York University \\ 4700 Keele St. Toronto ON, M3J 1P3 \\ Email: brichardson@osgoode.yorku.ca
}




\title{
The Ties That Bind: Indigenous Peoples AND ENVIRONMENTAL GOVERNANCE
}

\author{
Benjamin J. Richardson*
}

\section{THE ISSUES}

\section{A. HEADING 2}

\section{HEADING 3}

Indigenous peoples, at least traditionally, have often been regarded as exemplars of environmentally sustainable living. The impact of their subsistence livelihoods was apparently kept in check by customary laws to ensure they lived by the laws of nature. ${ }^{1}$ Today, some people see answers to our environmental crisis in these traditions. The United Nations' pioneering report, Our Common Future, proclaimed that: 'these communities are the repositories of vast accumulations of traditional knowledge and experience, [and] larger society ... could learn a great deal from their traditional skills in sustainably managing very complex ecological systems'. ${ }^{2}$ Could it thus be assumed that upholding Indigenous rights and conserving the environment go hand-in-hand? So, while states have often been hostile to Indigenous interests, in times of grave

* Osgoode Hall Law School, York University, Canada. I am grateful for the assistance of Sarah Robicheau in researching and writing this chapter.

See D Craig, 'Implications of Indigenous Rights and Customary Laws on the Development of Environmental Law for Sustainable Development' in L Sun and L Kurukulasuriya (eds), UNEP's New Way Forward: Environmental Law and Sustainable Development (UNEP, 1995); GA Klee (ed), World Systems of Traditional Resource Management (VH Winston and Sons, 1980).

2 World Commission on Environment and Development, Our Common Future (Oxford University Press, 1987) 114-15. 
environmental threats there will presumably be peaceful collaboration and the voices of Indigenous peoples will be respected.

Yet, for many reasons, the Aboriginal and environmental agendas often do not coincide. Putting aside the contrary historical record - when European colonisers plundered Indigenous lands, exterminating the herds of buffalo, damming the rivers, and felling the forests - the supposedly heightened environmental-consciousness of modern Western societies has not necessarily assuaged Indigenous peoples. The history of nature conservation in Africa provided one of the first hints that a vast chasm can arise between Western environmental policies and the interests of local communities. When colonial authorities in Africa set aside large territories as game reserves and parks, they evicted the native inhabitants to make way for places that would primarily serve the recreational and scientific interests of outsiders. ${ }^{3}$ Areas occupied by subsistence hunters and farmers for thousands of years suddenly were relabelled as 'wildernesses'. These callous policies set precedents that continue today, such as the evictions of the Bushmen of the Kalahari by the Botswana government. ${ }^{4}$

Likewise, modern environmental policy in the West can be the context for bitter disputes between Indigenous and non-Indigenous interests. They arise for many reasons. Sometimes governments' lofty environmental policies are sacrificed to short-term development interests, where the seeming riches of a new mine or logging concession trump any rival values Indigenous peoples or other environmentally-minded communities may attach to such lands. Conflicts may also arise in reconciling Indigenous traditional knowledge with the supposed hard 'objectivity' of Western science in environmental decision-making. Also, because of the prevalent belief that nature conservation depends on separating nature from humankind, the presence of Indigenous peoples can be seen as incompatible with the protection of endangered species and their habitats.

3 JM MacKenzie, The Empire of Nature: Hunting, Conservation and British Imperialism (Manchester University Press, 1988); RA Schroeder, 'Geographies of Environmental Intervention in Africa' (1999) 23(3) Progress in Human Geography 359.

C Timberg, 'Eviction of Bushmen Is Ruled Illegal' Washington Post (14 December 2006) A20. 
This chapter explores the relationships between Indigenous peoples and environmental governance. 'Governance', defined broadly, means the norms and decision-making processes by which society and its organisations are controlled and coordinated. ${ }^{6}$ While governance is habitually associated with official regulation by states, ${ }^{7}$ scholars in the field of legal pluralism are advancing more nuanced understandings that also emphasise the roles of non-state institutions in the market and civil society in policy-making, norm-setting, implementation, and other aspects of governance. ${ }^{8}$ Indigenous scholars such as John Borrows also stress the role of Indigenous communities and their legal traditions as a critical source of social ordering. ${ }^{9}$ For this chapter, therefore, environmental governance covers a range of values, norms, institutions and processes, both state- and non-state-based, that shape entitlements to use or benefit from natural resources, and to control their exploitation or protection.

Nominally, the importance of Indigenous involvement in environmental governance is now affirmed in many laws and policies. It is commonplace, for instance, to find references to Indigenous peoples in international environmental declarations, resolutions and policies. ${ }^{10}$

5 It builds on an extensive literature on the interaction between Aboriginal law and environmental law: see eg M Blumm, 'Retracing the Discovery Doctrine: Aboriginal Title, Tribal Sovereignty, and their Significance to Treaty-making and Modern Natural Resources Policy in Indian Country' (2004) 28 Vermont Law Review 713; D Curran and M M'Gonigle, 'Aboriginal Forestry: Community Management as Opportunity and Imperative' (1999) 37 Osgoode Hall Law Journal 711; E Goodman, 'Protecting Habitat for Off-Reservation Tribal Hunting and Fishing Rights: Tribal Co-Management as a Reserved Right' (2000) 30 Environmental Law 279; GD Meyers, 'Different Sides of the Same Coin: A Comparative View of Indian Hunting and Fishing Rights in the United States and Canada' (1991) 10 UCLA Journal of Environmental Law and Policy 67.

6 See generally M MacNeil, N Sargent and P Swan (eds), Law, Regulation and Governance (Oxford University Press, 2003).

7 OECD, Reforming Environmental Regulation in OECD Countries (OECD, 1996).

S Merry, 'Legal Pluralism' (1988) 22 Law and Society Review 869.

J Borrows, 'With or Without You: First Nations Law (in Canada)' (1995) 41 McGill Law Journal 629.

10 See BJ Richardson, 'Indigenous Peoples, International Law and Sustainability' (2001) 10(1) RECIEL 1; RK Hitchcock, 'International Human Rights, the 
Notably, the Rio Declaration on Environment and Development of 1992 declared:

indigenous people ... have a vital role in environmental management and development because of their knowledge and traditional practices. States should recognize and duly support their identity, culture and interests and enable their effective participation in the achievement of sustainable development. ${ }^{11}$

Given the attention this topic has acquired, this chapter has two specific aims. First, it examines the environmental values and practices of Indigenous peoples, primarily in order to assess their implications for the Indigenous stake in environmental governance. As these peoples seek greater involvement in environmental decision-making, it is worthwhile to understand the values that they bring to these processes. For instance, in establishing a national park or conducting an environmental impact assessment of a proposed mine, we should ask what values and knowledge are brought to decision-making when Indigenous peoples are involved. In what ways might resulting land use decisions differ?

Another reason to examine Indigenous environmental values and practices is because the push for Indigenous participation in environmental governance is often not merely grounded in Indigenous rights to natural resources, but also in the societal perceptions of the sustainability of Indigenous livelihoods. They are sometimes said to be more environmentally sustainable than Western lifestyles, thereby justifying giving Indigenous peoples more say in environmental management. Yet, as this chapter shows, in the scholarly and policy literature, a wide variety of theories and perspectives regarding Indigenous environmental values and practices can be found, not all of which see Indigenous cultures as consistently environmentally benign. We need to be aware of these theories and perspectives, because their legitimacy can influence the voice Indigenous peoples may have in environmental decision-making.

\footnotetext{
Environment and Indigenous Peoples' (1994) 5 Colorado Journal of International Environmental Law and Policy 1.

$11 \quad$ 1992, 31 ILM 876, Principle 22.
} 
The second aim of the chapter is to review the legal norms and governance tools that structure Indigenous involvement in environmental management, in order to assess their relative value for Indigenous stakeholders and implications for environmental care. The chapter focuses on examples in Australia, Canada, New Zealand and the United States (US), where some of the most substantial reforms for Indigenous participation in environmental governance have arisen. Some governance techniques emphasise access to natural resources, yet fail to provide a framework for the management of those resources. Some institutional mechanisms for resource management promote Indigenous selfgovernance, yet fail to resolve how Indigenous peoples can govern environmental impacts that emanate far beyond areas under tribal authority. In other words, governance frameworks based on Indigenous rights and other legal interests may not always be isomorphic with the dynamic properties of ecosystems and the disturbances they face.

The next section addresses the first stated aim of this chapter, namely to canvass the literature and evidence concerning the environmental knowledge and practices of Indigenous peoples and their contributions to sustainability. ${ }^{12}$ At least six major theories or perspectives are present. While the labels given to these perspectives are my own, they reasonably capture the gist of the various arguments and ideas in the scholarship and policy literature. As we review the material, the seminal question that should be borne in mind is this: what are the implications of such perspectives for Indigenous peoples' role in environmental governance?

\section{ENVIRONMENTAL - INDIGENOUS PEOPLES RELATIONSHIPS}

12 See H Brody, Maps and Dreams: Indians and the British Columbia Frontier (Douglas and McIntyre, 1988); D Brokensha, DM Warren and O Werner, Indigenous Knowledge Systems and Development (University Press of America, 1980); B DeWalt, 'Using Indigenous Knowledge to Improve Agricultural and Natural Resource Management' (1994) 53 Human Organization 123; JD Hughes, American Indian Ecology (Texas Western Press, 1983). 


\section{A. ECOLOGICAL GUARDiANS}

A common perspective in the literature portrays Indigenous peoples as prototypical environmentalists, living harmoniously with nature without indulging in the profligacy associated with Western culture. ${ }^{13}$ The close attachment to the land and the environment is described by some commentators as the 'defining characteristic of indigenous peoples'. 14 A study by a task force of the International Union for the Conservation of Nature (IUCN) trumpeted that Indigenous peoples 'are the sole guardian of vast habitats critical to modern societies ... [and] their ecological knowledge is an asset of incalculable value'. ${ }^{15}$ Other commentators contend that 'commercial consumption, exploitation of natural resources, and notions of enrichment are not part of indigenous cultures'. ${ }^{16}$ Thus, they should provide a salutary model for the rest of humanity. ${ }^{17}$ This perspective also strongly implies that protecting Indigenous rights should dovetail with those forms of modern environmental governance that stress sustainability. Indeed, the environmental movement often touts Aboriginal peoples as unfailing allies. ${ }^{18}$

Posey highlights several features of Indigenous livelihoods relevant to environmental sustainability, including: high levels of social co-operation, local-scale self-sufficiency and concern for the well-being of posterity. ${ }^{19}$ One example of the latter outlook in a Canadian Indigenous

13 See F Berkes, 'Traditional Ecological Knowledge in Perspective' in JT Inglis (ed), Traditional Ecological Knowledge: Concepts and Cases (International Development Research Centre, 1993) 1.

14 SH Davis (ed), Indigenous Views of Land and the Environment (World Bank, 1993) $\mathrm{x}$.

15 IUCN Inter-Commission Task Force on Indigenous Peoples, Indigenous Peoples and Sustainability: Cases and Actions (IUCN, 1997) 35.

16 JP Kastrup, 'The Internationalization of Indigenous Rights from the Environmental and Human Rights Perspective' (1997) 32 Texas International Law Journal 97, 114.

17 Eg, AT Durning, Guardians of the Land: Indigenous Peoples and the Health of the Earth (Worldwatch Institute, 1992) 6-7.

18 Eg, S Schwartzman and B Zimmerman 'Conservation Alliances with Indigenous Peoples of the Amazon' (2005) 19 Conservation Biology 721.

19 DA Posey, 'Culture and Nature: The Inextricable Link' in UNEP Cultural and Spiritual Values of Biodiversity (UNEP, 2000) 1, 4; see also Berkes, above n 13, 4; RE Johannes (ed), Traditional Ecological Knowledge: A Collection of Essays (IUCN, 1989). 
community is the Haudenosaunee's 'seven generations' principle. ${ }^{20}$ It has similarities to the modern international environmental principle known as 'intergenerational equity', requiring nations to ensure that their economic development does not compromise posterity's ability to enjoy a healthy environment. $^{21}$

Another factor cited as contributing to the sustainability of Indigenous cultures is their spiritual veneration of the natural world. Nature is often the wellspring of ancestral and creation stories, such as in the Dreamtime of Australia's Aborigines ${ }^{22}$ and the cosmologies of North American Indians. ${ }^{23}$ These spiritual values can underpin specific environmental norms. Indigenous communities may protect natural sites that are dedicated to ancestral spirits or deities. ${ }^{24}$ In New Zealand, the Māori treat many mountains as 'intensely scared'. ${ }^{25}$ Kenya's Bukusu protect wetlands for their function in holding cultural rites such as male circumcision ceremonies. ${ }^{26}$ Wildlife harvesting practices may be controlled by animal totems and the recognition of taboo species. ${ }^{27}$

The ecological guardianship thesis also cites the traditional environmental knowledge (TEK) of Indigenous peoples. ${ }^{28}$ They are active

The principle requires that one consider the effects of decisions on the seventh generation yet to be born. Similar concepts inform many Indigenous legal orders worldwide. See e.g. Indigenous Environmental Network, 'Bemidji statement on Seventh Generation Guardianship' (2006) at www.sehn.org/bemidji.html.

See GF Maggio, 'Inter/intra-generational Equity: Current Applications Under International Law for Promoting the Sustainable Development of Natural Resources' (1997) 4 Buffalo Environmental Law Journal 161.

A Voigt and N Drury, Wisdom of the Earth: The Living Legacy of the Aboriginal Dreamtime (Simon and Schuster, 1997).

SA Bhagwat and C Rutte, 'Sacred Groves: Potential for Biodiversity Management' (2006) 4 Frontiers in Ecology and the Environment 519.

J Ruru, 'Indigenous Peoples' Ownership and Management of Mountains: The Aotearoa / New Zealand Experience' (2004) 3 Indigenous Law Journal 111, 115.

RW Kareri, 'The Sociological and Economic Values of Kenya's Wetlands' in SA Crafter, et al (eds), Wetlands of Kenya: Proceedings of a Seminar an Wetlands of Kenya (IUCN, 1992) 99, 102.

J Colding and C Folke, 'The Relations Among Threatened Species, Their Protection, and Taboos' (1997) 1 Conservation Ecology 6.

See MA Altieri and LC Merrick, 'In Situ Conservation of Crop Genetic Resources through Maintenance of Traditional Farming Systems' (1987) 41(1) Economic Botany 98; GM Morin-Labatut and S Akhtar, 'Traditional 
environmental managers guided by eons of accumulated wisdom and expertise. ${ }^{29}$ Berkes defines TEK as 'experience acquired over thousands of years of direct human contact with the environment'. ${ }^{30}$ McGregor catalogues three sources of TEK: 'traditional knowledge' (passed from generation through elders, rituals, initiation and storytelling); 'empirical knowledge' (gained from observation); and 'revealed knowledge' (acquired through spiritual origins and recognised as a gift). ${ }^{31}$ Traditional knowledge of plants, animals and ecosystems informs specific management practices such as resource rotation to ensure that one favoured species is not unsustainably harvested. In Canada, the James Bay Cree use this method for managing beaver and fish populations. ${ }^{32}$ Countless other examples could be given. ${ }^{33}$

The notion of 'traditional', however, can be a mixed blessing for Indigenous peoples, for it can be used as an excuse to deny their involvement in contemporary environmental management to address new threats and issues such as climate change. TEK's relevance to contemporary environmental practice is thus a significant area of research, including its relationship to Western science in environmental decisions. ${ }^{34}$

Environmental Knowledge: A Resource to Manage and Share' (1992) 4 Development Journal of the Society for International Development 24.

29

SeE F Berkes, Sacred Ecology: Traditional ECOLOGICAL KNOWLEDGE AND RESOURCE MANAGEMENT (TAYLOR AND FRANCIS, 1999).

Berkes above n 13, 1 .

D McGregor, 'Coming Full Circle: Indigenous Knowledge, Environment and Our Future' (2004) 28 American Indian Quarterly 385, 388. See also RG Kuhn and $\mathrm{F}$ Duerden, 'A Review of Traditional Environmental Knowledge: An Interdisciplinary Canadian Perspective' (1996) 16(1) Culture 71, 73.

F Berkes, J Colding and C Folke, 'Rediscovery of Traditional Ecological Knowledge as Adaptive Management' (2000) 10(5) Ecological Economics 1251, 1255.

Berkes, above n 29, 61.

HP Huntingon, 'Using Traditional Ecological Knowledge in Science: Methods and Applications' (2000) 10(5) Ecological Applications 1270; E Sherry and H Myers, 'Traditional Environmental Knowledge in Practice' (2002) 15(4) Society and Natural Resources 345. 


\section{B. ENVIRONMENTAL ARCHITECTS}

Putting an even stronger gloss on the ecological guardianship thesis, related literature portrays Indigenous peoples as architects of benign environmental change through active landscape management over millennia. ${ }^{35}$ Durning notes that 'animal and planet populations in most of the world reflect not just the blind logic of natural selection; they also reflect human selection'. ${ }^{36}$ This position therefore rejects Western conservation concepts such as 'wilderness', as wrongly implying natural terrain never inhabited by humankind. Indigenous peoples have moulded and shaped the environment through fire burning, selective hunting and gathering, and other forms of husbandry.

In Australia, for instance, repeated seasonal burnings of woodlands and scrub contributed to a mosaic of vegetation that enhanced biological diversity. ${ }^{37}$ The forcible removal of Aborigines from the land by colonial authorities led to the loss of these fire management regimes, and precipitated a catastrophic loss of species that had become dependent on these seared landscapes. ${ }^{38}$ Worldwide, many Indigenous peoples continue to deploy fire as a way to manipulate environmental conditions, such as is practised by the Krahô in the savannas of Brazil. ${ }^{39}$ A UN report on the subject thus reasoned that there is 'a direct relation between cultural diversity, linguistic diversity and biological diversity and that the quickening pace of loss of traditional knowledge was having a corresponding devastating impact on all biological diversity' ${ }^{40}$

Another manifestation of the environmental architect thesis is the phenomenon of 'cultural landscapes'. These are natural areas that have acquired special cultural significance from thousands of years of human use, representing the permanent interaction between humans and their

35

BS Orlove and SB Brush, 'Anthropology and the Conservation of Biodiversity' (1996) 25 Annual Review of Anthropology 329.

Durning, above n 17, 18.

D Yiburak, et al, 'Fire Ecology and Aboriginal Land Management in Central Arnhem Land, Northern Australia: A Tradition of Ecosystem Management' (2001) 28 Journal of Biogeography 325.

T Flannery, 'Who Killed Kirlilpi?' (1989) 23 Australian Natural History 234. J Mistry, et al, 'Indigenous Fire Management in the Cerrado of Brazil: The Case of the Krahô of Tocantíns' (2005) 33 Human Ecology 365

This was noted in the Workshop on Traditional Knowledge and Biological Diversity Report of the Workshop (UNEP, 1997) 2. 
environment. The concept of cultural landscapes has been recognised under the World Heritage Convention. ${ }^{41}$ New Zealand's Tongariro National Park, a sacred region to Māori, was the first cultural landscape listed under the Convention for international protection. ${ }^{42}$ Protected areas management in this country and others, including Canada and the US, is being transformed by the philosophy that in many landscapes the natural and cultural heritage are inextricably bound together and that conservation can benefit from more integration between the two. ${ }^{43}$ One governance consequence of this approach is that ongoing management of such sites should involve the people who are most culturally associated with them. ${ }^{44}$

\section{MisGuided ENVIRONMENTALISTS}

Some environmental historians and scientists dispute views that Indigenous peoples generally lived in blissful harmony with nature. ${ }^{45}$ They indict some communities for environmental degradation, citing historical evidence in areas under Indigenous occupation. While such findings may seem irrelevant to contemporary environmental debates about Indigenous peoples, some of the evidence involves more recent transformations such as in South Pacific, ${ }^{46}$ and the research can provide ammunition for those seeking excuses to limit Indigenous environmental rights today.

\footnotetext{
$41 \quad$ 1972, 27 UST 37, 11 ILM 1358.

42 S Forbes, 'Tongariro National Park World Heritage Cultural List "He Koha Tapu - A Sacred Gift"' (Government of New Zealand, 1993).

$43 \quad \mathrm{~N}$ Mitchell and S Buggey, 'Protected Landscapes and Cultural Landscapes: Taking Advantage of Diverse Approaches' (2000) 17 George Wright Forum 1. Ibid, 43.

LM Shields, 'Are Conservation Goals and Aboriginal Rights Incompatible?' (2000) 10 Journal of Environmental Law and Practice 187; AM Stearman, 'Revisiting the Myth of the Ecologically Noble Savage in Amazonia: Implications for Indigenous Land Rights' (1994) 49 Culture and Agriculture 2; MS Alvard, 'Testing the "Ecologically Noble Savage' Hypothesis' (1993) 21 Human Ecology 355.

46 JBC Jackson, et al, 'Historical Overfishing and the Recent Collapse of Coastal Ecosystems' (2001) 293 Science 630; but see the robust counter arguments in RE Johannes, 'Did Indigenous Conservation Ethics Exist?' (2002) 14 SPC Traditional Marine Resource Management and Knowledge Information Bulletin 3.
} 
Several reasons for associating Indigenous peoples with environmental decline are advanced. Firstly, when Indigenous peoples moved into an area unaccustomed to hman beings for the first time, such as in the arrival of the first people in North America estimated at some 11,000 years ago or the Māori in New Zealand 1000 years ago, ${ }^{47}$ animal species were naive to the hunting threat posed by the newcomers. ${ }^{48}$ Indigenous settlers may have lacked awareness of the relative scarcity of unfamiliar natural resources and had not evolved quickly enough the requisite social norms to limit exploitation. Tim Flannery, a scientist who has documented such ecological changes, describes the arrival of Māori hunters as precipitating a 'blitzkrieg extinction' in which some 12 species of moa (giant birds, most larger than ostrichs) were exterminated within a few centuries. ${ }^{49}$ In North America, the influx of Clovis hunters is cited as an seminal factor in the demise of some 35 primarily large mammals, including mammoths. ${ }^{50}$ However, the evidence of such impacts is disputed. $^{51}$

Another factor linking environmental wastefulness to Indigenous peoples relates to the impact of their spiritual systems. Ironically, their deep spiritual attachment to nature may have blinded them to evidence of their real ecological impacts. The great reverence some Indigenous peoples have had for their environment may have fed beliefs that nature, nourished by mystical forces, provided an unlimited bounty. North American historian Dan Flores quotes a $19^{\text {th }}$ century report regarding bison hunting:

47 These dates are the most widely cited in the literature, but are disputed by many including by Indigenous peoples.

$48 \quad$ See J Diamond, The Rise and Fall of the Third Chimpanzee (Vintage, 1992); R Edgerton, Sick Societies: Challenging The Myth of Primitive Harmony (Maxwell MacMillan, 1992); T Flannery, The Future Eaters (Reed Books, 1995); T Flannery, The Eternal Frontier (Atlantic Monthly Press, 2001); KH Redford and AM Stearman, 'Forest-Dwelling Native Amazonians and the Conservation of Biodiversity: Interests in Common or in Collision?' (1993) 7 Conservation Biology 248.

$49 \quad$ Flannery, Future Eaters, above n 48, 195.

$50 \quad$ See G Haynes, 'The Catastrophic Extinction of North American Mammoths and Mastodonts' (2002) 33 World Archaeology 391.

51 See DK Grayson and DJ Meltzer, 'Clovis Hunting and Large Mammal Extinction: A Critical Review of the Evidence' (2002) 16 Journal of World Prehistory 313. 
[e]very Plains Indian family firmly believed that the buffalo were produced in countless numbers in a country under the ground, that every spring the surplus swarmed like bees from a hive, out of great cave-like openings ...

Alternatively, some research on other communities doubts that spiritual beliefs were sufficiently potent to cause Indigenous peoples' to moderate their behaviour in response to environmental depletion. Colchester suggests that 'many studies show little correlation between beliefs prescribing certain practices and actual behaviour'. ${ }^{53}$ With regard to Amazonia Indians, Colchester notes that many 'have an opportunist rather than conservationist attitude to the environment, and achieve ecological balance because their traditional political systems and settlement patterns encourage mobility'. 54 Low population densities and technological restraints are other factors cited that might have kept the environmental burden of Indigenous peoples unintentionally relatively low. ${ }^{55}$

In sum, these arguments essentially claim that Indigenous peoples, like other human cultures, do not possess some innate ecological wisdom etched in their genes; rather, their environmental relationships and impacts are contingent, depending on the particular customs, values and social practices of a given community. For contemporary environmental governance, the past, however, is not necessarily a guide to the present. While we should be mindful that no human culture is infallible, the contribution of Indigenous communities to environmental care should be assessed on a case-by-case basis and not crudely inferred on the basis of distant, historical evidence.

\section{FORESAKEN ENVIRONMENTALISTS}

A fourth argument in some scholarship holds that, whatever the merit of claims that Indigenous peoples were ecological stewards or architects, the

52 D Flores, 'Bison Ecology and Bison Diplomacy: The Southern Plains from 1800 to 1850 ' (1991) 78 Journal of American History 483.

53 M Colchester, Salvaging Nature: Indigenous Peoples, Protected Areas and Biodiversity Conservation (World Wide Fund for Nature, 1994) 27.

$54 \quad$ Ibid.

55 S Krech III, The Ecological Indian: Myth and History (WW Norton and Co, 2000) (discussing North American natives). 
cold reality is that Indigenous livelihoods have often changed irreparably. ${ }^{56}$ Urban living, displacement and migration, technological changes and the influence of the market economy, are among the miscellany of factors transforming Indigenous culture. These social and economic changes have removed many Indigenous peoples from the traditional hunter-gatherer lifestyle, thereby weakening the traditional customary laws and norms to control inappropriate environmental behaviour in other contexts. ${ }^{57}$ The integrity and relevance of Indigenous communities' environmental values is questioned when their members live increasingly in urban areas outside tribal structures and the traditional, subsistence economy. While it would be grossly naïve to contend that Indigenous cultures have remained untainted by centuries of colonialism, we should be careful about implying that they have been ill-fated and lack the will to adapt successfully to changing circumstances, as another scholarly perspective examined later in this chapter contends.

Nonetheless, some cultural changes, with environmental consequences, have been documented even for Indigenous peoples continuing to subsist on the land. For example, Alaskan natives have been implicated in destructive forestry practices. ${ }^{58}$ Even in relatively remote places, such as in the highlands of Papua New Guinea, Flannery found resource depletion pressures from population growth and access to more efficient hunting technologies. ${ }^{59}$ These trends may imply that Indigenous people have not yet evolved the necessary new norms to control the pressures posed by increased numbers and new technologies.

56 Eg, DR Lewis, 'Native Americans and the Environment: A Survey of Twentieth-Century Issues' (1995) 19 American Indian Quarterly 423; R Meher, 'The Social and Ecological Effects of Industrialisation in a Tribal Region: The Case of the Rourkela Steel Plant' (1998) 57 American Journal of Economics and Sociology 105; CR Ramirez, 'Ethnobotany and the Loss of Traditional Knowledge in the 21st Century' (2007) 5 Ethnobotany Research and Applications 245.

57 Redford and Stearman, above n 48, 252; Colchester, above n 53, 26.

$58 \quad$ F Cassidy and N Dale, After Native Claims: The Implications of Comprehensive Claims Settlements for Natural Resources in British Columbia (Oolichan Books, 1988) 104-7.

59 T FLANNERY, Throwim WAy Leg: Tree-Kangaroos, Possums, AND Penis GOURDS - ON THE TRACK OF UNKNOWN MAMMALS IN WiLDEST NEW GuINEA (TEXT PUBLISHING, 1998). 
These changes to Indigenous livelihoods have sometimes led Aboriginal peoples to tolerate or welcome commercial developments that mainstream environmental groups oppose. For example, a 1991 public inquiry into mining on Aboriginal lands in a conservation zone in northern Australia found that:

[t]he Jawoyn do not oppose mining per se. .... A number of Jawoyn people are in favour of mining ... They do not consider [the affected lands] as significant culturally or religiously, although they express concerns about disturbance to certain sites outside the Zone. These promining Jawoyn people appear to be motivated by a desire for personal and community advancement in a context of limited alternative employment opportunities and welfare dependency. ${ }^{60}$

The nature of contemporary Indigenous environmental practices is also being questioned in other contexts. One example is the resumption of whaling. Animal welfare and environmental groups have criticised the International Whaling Commission's rules permitting subsistence hunting by some Aboriginal groups. The stated concerns are the threats to endangered cetaceans and that harvested whale meat is being traded commercially. ${ }^{61}$ Another concern is the 'bush meat' crisis in Africa, where civil strife and the breakdown of traditional community institutions has fueled rampant, unsustainable hunting of wildlife. ${ }^{62}$ The primary factors in this crisis however are probably not dysfunctional Indigenous management practices per se, but rather the growing intrusion of outside

$60 \quad$ Resource Assessment Commission, Kakadu Conservation Zone Inquiry: Final Report and Summary (AGPS, 1991) 7-8. Indigenous organizations in the Canadian North have also welcomed and participated in numerous mining, oil and gas ventures: eg, R Boychuk, 'The Road from Bathurst Inlet' 124(2) Canadian Geographic 40; Inuvialuit Corporate Group, Annual Report 2002 (Inuvialuit Regional Corporation, 2003).

61 R Black, "Greenland Whale Hunt "Commercial"' BBC News online (17 June 2008); L Jenkins and C Romanzo, 'Makah Whaling: Aboriginal Subsistence or a Stepping Stone to Undermining the Commercial Whaling Moratorium (1998) 9 Colorado Journal of International Environmental Law and Policy 71.

62 MI Bakarr, et al, 'Hunting and Bushmeat Utilization in the African Rain Forest' (2001) 2 Advances in Applied Biodiversity Science 170. 
economic and social factors associated with commercial forestry and oil exploration, as well as military conflicts. ${ }^{63}$

Whatever the veracity of its claims, the foresaken environmentalist thesis should not be an excuse to deny Indigenous involvement in modern environmental governance. Indigenous environmental rights should not be reduced to a crude calculation of their functional value to wider society. If this standard were adopted, it would also be a reason to rebuff mining companies, fishing businesses and many other economic interests with appalling environmental records. Rather, we need to find ways to allow Indigenous communities to rebuild their ties to the land and, to the extent that there are limitations to Indigenous knowledge, expertise and capacity, to look to cross-cultural approaches to resource management that combine Indigenous and non-Indigenous stakeholders'strengths.

\section{E. ENVIRONMENTAL VICTIMS}

A fifth perspective in the literature stresses that Indigenous peoples are primarily victims, not perpetrators of, environmental harm. ${ }^{64}$ Scholars such as Westra and Howitt highlight the conscription of Indigenous resources into the cash economy through dams, mines and other projects that have had ruinous consequences for native lands and communities. ${ }^{65}$ These projects have undermined the economic foundations of Indigenous communities, spawned various public health problems, and fuelled a host

M Thibault and S Blaney, 'The Oil Industry as an Underlying Factor in the Bushmeat Crisis in Central Africa' (2003) 17 Conservation Biology 1807. Eg, D Brook, 'Environmental Genoicde: Native Americans and Toxic Waste' (1998) 57 American Journal of Economics and Sociology 105; T Nachowitz, 'Repression in the Narmada Valley, India' (1988) 12(3) Cultural Survival Quarterly 23; R Niezen, 'Power and Dignity: The Social Consequences of Hydro-electric Development for the James Bay Cree' (1993) 30 Canadian Review of Sociology and Anthropology 510.

Peoples (Taylor and Francis, 2001); L Westra, Environmental Justice and the Rights of Indigenous Peoples - International and Domestic Law Perspectives (Earthscan Publishers, 2007). 
of collateral cultural impacts. ${ }^{66}$ To the extent that Indigenous communities are complicit in any of these activities, this perspective implies that it would be a context not of their making. Robbed of their lands and denied a viable economic resource base, Indigenous peoples sometimes partake in environmentally problematic developments only as a result of limited options. ${ }^{67}$

Indigenous peoples, of course, have not necessarily been hapless bystanders to the juggernaut of the market economy. They have often fiercely resisted forestry ${ }^{68}$ and extractive industry ${ }^{69}$ projects on their lands. Open-cut mines undertaken by transnational corporate behemoths at $\mathrm{Ok}$ Tedi (Papua New Guinea), Freeport (Indonesia) and Jabiluka (Australia) have engendered some titanic conflicts. ${ }^{70}$ Big dams have also ignited clashes, such as Quebec's damming of the James Bay River ${ }^{71}$ and India's Narmada River dam. ${ }^{72}$ The flooding of traditional hunting grounds and the physical displacement of whole communities were a high price to pay in the name of national economic development in both cases. According to the World Dams Commission, large dams in India displaced between 16

66 LA Lambert, Keepers of the Central Fire: Issues in Ecology for Indigenous Peoples (Jones and Bartlett Publishers, 1999).

67 J Borrows, 'Living between Water and Rocks: First Nations, Environmental Planning and Democracy' (1997) 47 University of Toronto Law Journal 417, 424 (discussing Native Americans' involvement in commercial forestry). P Utting, Trees, People and Power. Social Dimensions of Deforestation and Forest Protection in Central America (Earthscan, 1993); L Starke (ed), Breaking New Ground: Mining, Minerals, and Sustainable Development. The Report of the MMSD Project (Earthscan, 2002).

69 See RT Libby, Hawke's Law: The Politics of Mining and Aboriginal Land Rights in Austrailia (University of Western Australia Press, 1989).

70 Eg, C Ballard and G Banks, 'Resource Wars: The Anthropology of Mining' (2003) 32 Annual Review of Anthropology 287; S Cuffe, 'Global Actors, Mining and Community-Based Resistance in Honduras and Guatemala' (Rights Action, 2005); A Gedicks, The New Resource Wars: Native and Environmental Struggles Against Multinational Corporations (South End Press, 1993).

$71 \quad$ R Niezen, 'Power and Dignity: The Social Consequences of Hydro-electric Development for the James Bay Cree' (1993) 30 Canadian Review of Sociology and Anthropology 510.

72 C Alvares and R Billorey, Damming the Narmada: India's Greatest Planned Environmental Disaster (Third World Network, 1988); T Nachowitz, 'Repression in the Narmada Valley, India' (1988) 12(3) Cultural Survival Quarterly 23. 
and 38 million people from 1950 to 1990 , and about 40 per cent of those displaced were tribal people. ${ }^{73}$

Recently, the long-range environmental impacts of 'dominant' societies upon Indigenous peoples have become a cause for possibly greater concern. ${ }^{74}$ These impacts include toxic contamination in the Arctic food chain and global warming. Such problems illustrate the cruel irony of Indigenous peoples' situation: not only are those closest to nature the worst impacted by environmental degradation, but Western societies often impose environmental harms on Indigenous societies from afar.

Even seemingly environmentally benign policies can hurt. Most notably, the creation of nature conservation parks can displace Indigenous peoples, removing them from their traditional hunting and foraging grounds. ${ }^{75}$ Bernard Grzimek, one of the colonial-era architects of East Africa's extensive network of protected areas, once said: '[a] National Park ... must remain a primordial wilderness to be effective. No men, not even native ones, should live inside its borders'. ${ }^{76}$ This philosophy continues to permeate nature conservation policies in some countries. ${ }^{77}$

The environmental victims thesis has various implications for environmental governance. The two most significant are the need for compensation and other remedies for dsiplaced and injured Indigenous communities and, to address future threats, to ensure much greater Indigenous voice in environmental decision-making. The emerging international principle of an Indigenous right to 'free, prior and informed consent' is an obvious legal standard to prevent creating more Indigenous

73 World Dams Commission (WDC), Dams and Development (WDC, 2000) 104, 110 .

74 DL Brown, 'Toxic-tainted Arctic Animals Passing Poisons on to Inuit' (May 22, 2001) Seattle Times.

75 See examples detailed in World Rainforest Movement (WRM) 'Protected Areas: Protected Against Whom?' (WEM January, 2004); E Kemf (ed), Indigenous Peoples and Protected Areas. The Law of Mother Earth (Earthscan, 1993).

76 Cited in JS Adams and TO McShane, The Myth of Wild Africa: Conservation Without Illusion (WW Norton and Co, 1992) xvi.

77 R Poirier and D Ostergren, 'Evicting People from Nature: Indigenous Land Rights and National Parks in Australia, Russia, and the United States' (2002) 42 Natural Resources Journal 331. 
victims by allowing communities to veto inappropriate development projects. $^{78}$

\section{F. ENVIRONMENTAL INNOVATORS}

We should also be aware that some Indigenous communities have successfully adapted to demographic, economic and technological changes, maintaining and innovating robust systems of environmental management that can address contemporary challenges. ${ }^{79}$ In this sixth scholarly perspective, Indigenous knowledge is not simply a relic of ancient hunter-gatherer societies, but continues to be relevant and adaptable to modern resource management situations. ${ }^{80}$ Through greater Indigenous self-governance, Aboriginal peoples seek a framework to apply their skill and wisdom to natural resources management. ${ }^{81}$

One World Bank report summarised several examples of the contemporary relvance of TEK and social practices, noting that

[t]he the pastoral peoples of eastern Africa -- who for so long have been identified by Western livestock specialists as a major cause of arid and semi-arid land problems -- are today recognized as possessing sophisticated knowledge about range and animal management, including strategies

78 JP Rosenthal, 'Politics, Culture, and Governance in the Development of Prior Informed Consent in Indigenous Communities' (2006) 47 Current Anthropology 119.

79 See KK Misra (ed), Traditional Knowledge in Contemporary Societies: Challenges and Opportunities (Pratibha Prakashan, 2007); N Turner, The Earth's Blanket: Traditional Teachings for Sustainable Living (University of Washington Press, 2005); M Gadgil, F Berkes and C Folke, 'Indigenous Knowledge for Biodiversity Conservation' (1993) 22 Ambio 151.

80 AL Booth and HM Jacobs, 'Ties That Bind: Native American Beliefs as a Foundation for Environmental Consciousness' (1990) 12 Environmental Ethics 27.

81 A Ross and K Pickering, 'The Politics of Reintegrating Australian Aboriginal and American Indian Indigenous Knowledge into Resource Management: The Dynamics of Resource Appropriation and Cultural Revival' (2002) 30 Human Ecology 187. 
for adapting to periodic drought and other natural calamities. $^{82}$

In developed countries, where Indigenous minorities often have endured even greater cultural and economic pressures, there is similarly evidence of a growing appreciation of Indigenous environnmental practices. For example, Aborigines' traditional fire management techniques have been reintroduced in some outback national parks in Australia to restore biological diversity that co-evolved in response to periodic burning of the savanna ${ }^{83}$ In Canada, the National Aboriginal Forestry Association (NAFA) drafted the Aboriginal Forest Land Management Guidelines, setting 'out a broad and flexible framework for Aboriginal peoples to develop and implement community- and ecosystem-based forest management planning that takes into account multiple forest values' ${ }^{84}$ Countless other encouraging examples could be given.

One worth commenting on is the Centre for Indigenous Environmental Resources (CIER), in Canada. Established in 1994, CIER illustrates the new generation of Indigenous organisations fashioning environmental governance. Using grass-roots approaches, it advises and facilitates communities' involvement in the environmental planning and management. For instance, CIER has initiated projects for 'identifying economic, environmental, social, and cultural solutions and options for First Nations to better adapt to climate change' ${ }^{85}$ It is also supporting the Assembly of First Nations to launch a Plan of Action for Drinking Water in First Nations Communities. ${ }^{86}$ Its work on legal aspects of sustainability includes a research report on First Nations Governance Success Stories and an Indigenous Laws project to document the contribution of TEK and customary laws to environmental protection. ${ }^{87}$

\footnotetext{
$82 \quad$ Davis, above $\mathrm{n} 14, \mathrm{x}$

83 R Kimber, 'Black Lightning: Aborigines and Fire in Central Australia and the Western Desert' (1983) 18 Archaeology in Oceania 38.

84 NAFA, Aboriginal Forest Land Management Guidelines: A Community Approach (NAFA, 1995).

85 Centre for Indigenous Environmental Resources: www.cier.ca/taking-action-onclimate-change.

86 See Plan of Action for Drinking Water in First Nations Communities. Progress Report (Indian and Northern Affairs Canada, 2008), www.aincinac.gc.ca/H2O/prpf/wpr3-eng.asp\#bkg.

87 See www.cier.ca/building\%2Dsustainable\%2Dcommunities.
} 
The environmental innovation thesis presents one of the most forceful arguments for bolstering the Indigenous voice in the governance of their lands and resources. It coincides with a plethora of scholarship that calls for democratising and decentralising environmental decision-making to community-levels. ${ }^{88}$

\section{G. OTHER PeRsPectives}

While none of the foregoing perspectives in the scholarly literature alone provide a sufficiently plausible account of all Indigenous peoples' relationships to the environment, each appears to hold some truth in some situations, depending on the time, place and community. Indigenous peoples are multi-cultural, with a diversity of values, customs and social practices. Their relationships with the environment therefore vary. Historically, some tribes were hunter- gatherers, while others were partialagriculturalists; some were nomadic while others more settled, depending on available natural resources. Today, some communities have successfully adapted to new environmental threats and conditions, while others have struggled.

A few further arguments about this topic should be noted, before examining Indigenous participation in environmental governance. First, regardless of their environmental impacts, we should be careful of implying that Indigenous peoples should be held to a higher environmental standard. Industrial societies, with their vastly greater environmental burden, are hardly qualified to pass judgement on Indigenous livelihoods. Nuclear weapons, toxic chemicals and urban sprawl are some of the appalling legacies of modern society that dwarf even the most damning environmental evidence against Indigenous peoples.

Conversely, we also should be wary of arguments that romanticise Indigenous people as ecological guardians. They can foster harmful stereotypes, implying expectations of Indigenous peoples that are and Row, 1973); J Agyeman and B Evans, 'Sustainability and Democracy: Community Participation in Local Agenda 21' (1995) 22(2) Local Government Policy Making 35; G Smith, Deliberative Democracy and the Environment (Routledge, 2003). 
unrealistic in an environmentally depleted world. ${ }^{89}$ Stereotyping them as ecological guardians can hurt and hinder Indigenous cultural evolution. Likewise, when we contrast Indigenous environmental values with those of non-indigenous cultures, we should also avoid stereotyping the latter. In fact, within Western environmental traditions there are diverse philosophies and practices, including deep ecologism and animal liberationism. ${ }^{90}$

The following sections canvass the legal standards and rights developed in international and domestic law pertaining to Indigenous peoples and their environments. ${ }^{91}$ Legal rights and institutions are critical, because most commentators agree that Indigenous communities are more likely to continue environmentally sustainable practices and to maintain their cultural integrity when they enjoy territorial security and autonomy. ${ }^{92}$ Where ownership of the land is in the hands of the traditional owners, they are in a much stronger position to control its environmental management. ${ }^{93}$ Yet, because Indigenous self-determination and environmental protection may not always be mutually reinforcing, others institutions are needed to reconcile Indigenous livelihoods (as with all lifestyles) with overarching collective responsibilities to safeguard the planet.

$89 \quad$ See D Waller, 'Friendly Fire: When Environmentalists Dehumanize American Indians' (1996) 20(2) American Indian Culture and Research Journal 107.

90 See R Eckersley, Environmentalism and Political Theory: Toward an Ecocentric Approach (SUNY Press, 1992); M Fox, Toward a Transpersonal Ecology: Developing New Foundations for Environmentalism (Shambala, 1990); D Pepper, Modern Environmentalism: An Introduction (Routledge, 1996).

91 Small portions of this discussion draw on the author's previous writings in BJ Richardson and D Craig, 'Indigenous Peoples, Law and the Environment' in BJ Richardson and S Wood (eds), Environmental Law for Sustainability (Hart Publishing, 2006) 195.

92 JB Alcorn, 'Noble Savage or Noble State? Northern Myths and Southern Realities in Biodiversity Conservation' (1994) 2(3) Ethnoecologica 7; Posey, above $\mathrm{n} 19$.

93 See L Burton, 'Indigenous Peoples and Environmental Policy in the Common Law Nation-States of the Pacific Rim: Sovereignty, Survival, and Sustainability' (1998) Colorado Journal of International Environmental Law Yearbook 136; JM Glenn and AC Drost, 'Aboriginal Rights and Sustainable Development in Canada’ (1999) 48 International and Comparative Law Quarterly 176. 
[VOL. 04 No. 05

\section{INDIGENOUS ENVIRONMENTAL GOVERNANCE: A TYPOLOGY OF APPROACHES}

\section{A. LEGAL PluRALISM AND INDIGENOUS LEGAL TRADITIONS}

Before canvasing environmental governance approaches, it is worth noting that they all reflect in some ways a shift toward more pluralistic and eclectic legal regimes, as evident in modern governance generally. ${ }^{94}$ Legal pluralism essentially refers to 'a situation in which two or more legal systems coexists in the same social field'. ${ }^{95}$ Virtually all societies blend official state-based and informal non-state methods of social ordering. ${ }^{96}$ Often legal pluralism is associated with reforms to formally acknowledge a separate space in state law for an alternate legal order derived from other legal traditions. Sack has emphasised that authentic legal pluralism 'is more than the acceptance of a plurality of law; it sees this plurality as a positive force to be utilised-and controlled-rather than eliminated' ${ }^{97}$ Such arrangements are found in Great Britain and Canada (accomodating civil legal systems in Scotland and Quebec respectively), for example.

States are also accommodating Indigenous legal traditions, although rarely to the extent of treating them as of equal status. Discrete areas such as family law and criminal justice are being opened up to Indigenous laws and decision-making customs. ${ }^{98} \mathrm{~A}$ few states have tinkered with more substantial accommodations, including constitutionallevel recognition of the distinct status of their Indigenous peoples. ${ }^{99}$ In Scandinavia, each country has established a Sámi parliament comprising individuals elected by and among the Sámi. These are advisory bodies

94 See generally MB Hooker, Legal Pluralism: An Introduction to Colonial and Neo-Colonial Laws (Clarendon Press, 1975).

$95 \quad$ S Merry, 'Legal Pluralism' (1988) Law and Society Review 869, 871.

$96 \quad$ J Griffiths, 'What is Legal Pluralism?' (1986) 24 Journal of Legal Pluralism 1.

97 P Sack, 'Legal Pluralism: Introductory Comments' in P Sack and E Minchin (eds), Legal Pluralism: Proceedings of the Canberra Law Workshop VII (Australian National University, 1988) 1. Selected Marriage and Adoption Cases' (1984) 4 Canadian Native Law Reporter 1.

99 See DL Van Cott, Indigenous Peoples and Democracy in Latin America (St Martin's Press, 1984). 
primarily responsible for the review of policies and proposed legislation of concern to Sámi. Norway's Sámi Act 1987 obliges 'state authorities to create the conditions necessary for the Sámi to protect and develop their language, their culture and their society'. ${ }^{100}$

As we shall later see, environmental law in some countries is also being infused with Aboriginal values, customs and practices. Sometimes, it appears that Indigenous peoples are offered more control over land and natural resources only on condition that, in the interests of environmental sustainability, they assume responsibility for conserving the few forests or other environmental resources left, and limit their economic aspirations accordingly. Thus, we should be aware that legal pluralism may largely perpetuate 'legal centrism', reinforcing the existing hierarchy of normative ordering, with state-based regulation at the apex. ${ }^{101}$

While Indigenous peoples' assertion of their legal traditions has been tied largely to their conflicts with specific nation-states, some of their initiatives transcend the dominant state-based framework of national and international law. For example, the Inuit Circumpolar Conference brings together Indigenous peoples from across the Arctic regions of several jurisdictions. ${ }^{102}$ Indigenous groups are expressing their own environmental agenda in other ways. These include international statements such as the Kari-Oca Declaration ${ }^{103}$ adopted at the tribal forum parallel to the 1992 Earth Summit, and the Charter of the Indigenous and Tribal Peoples of the Tropical Forests adopted at an international meeting in Malaysia. ${ }^{104}$

Not only may Indigenous peoples seek to by-pass the state, the state itself is off-loading or losing some of its regulatory responsibilities to the market. In turn, therefore, Indigenous groups must reckon with the power of markets to influence states' law-making activities or to generate their own, rival legal orders. The movement for corporate social

100 The text of the Sámi Act 1987 is set out in (1996) 1 Australian Indigenous Law Reporter 286.

101 W Tie, Legal Pluralism: Toward a Multicultural Conception of Law (Ashgate, 1999) 162, 167.

102 Inuit Circumpolar Conference: www.inuitcircumpolar.com.

103 Reproduced in M Terena, 'The Kari-Oca Conference in Rio' in L van de Fliert (ed), Indigenous Peoples and International Organisations (Spokesman Books, 1994) 181.

104 Charter of the Indigenous-Tribal Peoples of the Tropical Forests, February 1992, Malay, available at homepage of the International Alliance of the IndigenousTribal Peoples of the Tropical Forests, at www.gn.apc.org/iaip/chart/char1.html. 
responsibility has spawned various codes of conduct and market-based standards for business behaviour. For example, the Equator Principles, a voluntary code of conduct devised by the banking sector for socially and environmentally responsible financing, includes provisions regarding consultation with affected Indigenous communities. ${ }^{105}$ The strategies needed to influence private banks are not necessarily the same as those that will sway public governments.

\section{B. HistoricAl PERSPECTIVES}

Historically, Indigenous peoples secured toe-hold acknowledgement of their hunting and other subsistence activities in treaties imposed by colonial authorities - though at the terrible price of ceding vast swathes of their traditional territories. In North America, the eighteenth century treaties were negotiated to maintain peace, trade, alliance and military support. ${ }^{106}$ The Canadian Supreme Court in the Marshall case interpreted a 1760 treaty between the Mi'kmaq people and the British Crown as guaranteeing their rights to fish for a moderate livelihood in return for their allegiance to the Crown in its war against France. ${ }^{107}$

As European colonisers became more numerous and powerful during the nineteenth century, treaties served essentially to confiscate and plunder Indigenous lands. ${ }^{108}$ The better organised communities that were able to mount armed resistance, such as New Zealand's Māori, usually were best placed to negotiate fairer terms. The Treaty of Waitangi of 1840 provided that the Crown

guarantees to the Chiefs and Tribes of New Zealand ... the full exclusive and undisturbed possession of their Lands and Estates Forests Fisheries and other properties which

105 BJ Richardson, Socially Responsible Investment Law: Regulating the Unseen Polluters (Oxford University Press, 2008) 473-74.

106 See LG Robertson, Conquest by Law: How the Discovery of America Dispossessed Indigenous Peoples of their Land (Oxford University Press, 2005).

$107 \quad R v$ Marshall [1999] 3 SCR 456; see further LI Rotman, "My Hovercraft Is Full of Eels": Smoking Out the Message of R. v. Marshall' (2000) 63 Saskatchewan Law Review 617.

108 See S Carter, Aboriginal People and Colonizers of Western Canada to 1900 (University of Toronto Press, 1999). 
they may collectively or individually possess so long as it is their wish and desire to retain the same in their possession. $^{109}$

Yet, differences in cultural understandings, intentions and assumptions underpinning such treaties often greatly reduced their significance. Notoriously, for instance, in the Wi Parata judgement of 1877 the New Zealand Supreme Court dismissed the Treaty of Waitangi

as a simple nullity. No body politic existed capable of making a cession of sovereignty ... So far as the proprietary rights of the natives are concerned, the so-called treaty merely affirms the rights and obligations which, jure gentium, vested in and devolved upon the Crown. ${ }^{110}$

Consequently, many disputes about the failure to honour treaty obligations linger. Modern treaty negotiations, such as those for comprehensive land claims agreements in Canada, have been pursued with heightened expectations of greater equity and a guaranteed land and natural resources base for Indigenous participants. ${ }^{11}$

In the modern era, a notable trend, particularly in Latin America, is the constitutionalising of Indigenous rights. Constitutional law enunciations have often explicitly acknowledged Indigenous environmental-related rights and interests. The Paraguayan Constitution recognises the right of Indigenous peoples to preserve and develop their ethnic identity; the right to freely apply their system of political, social, economic, cultural and religious organisation; and their right to enforce customary law. ${ }^{112}$ The Constitution of Peru, inter alia, allows Indigenous institutions to exercise judicial functions pursuant to their customary law within their territory. ${ }^{113}$ The Bolivian Constitution guarantees Indigenous peoples' use and sustainable exploitation of their traditional natural

$109 \quad$ Art 2.

Wi Parata $v$ Bishop of Wellington (1877) 3 NZ Jur (OS) SC 72, 78.

BJ Richardson, D Craig and B Boer, Regional Agreements for Indigenous Lands and Cultures in Canada (Australia National University, 1995).

112 Constitución de la República de Paraguay, 1992, art 63.

113 Constitución Política del Perú de 1993, art 149. 
resources. ${ }^{114}$ Such provisions, however, sometimes masquerade continuing human rights abuses. Constitutional law precepts can be too vague and nonjusticiable to meaningfully accommodate Indigenous legal traditions. Furthermore, enforcement of such provisions has tended to lag considerably in a region where the rule of law often has a fragile status. ${ }^{115}$

Since the 1980s some international legal instruments have also recognised Indigenous legal traditions, which should help to nurture more pluralist environmental law regimes locally. Both the ILO Convention Concerning Indigenous and Tribal Peoples in Independent Countries ${ }^{116}$ of 1989 and the UN Declaration on the Rights of Indigenous Peoples ${ }^{117}$ of 2007 address rights to territory and natural resources, as detailed further in Claire Charters' chapter in this book. The Declaration proclaims Indigenous peoples' rights to own, develop and control the use of their traditional lands, ${ }^{118}$ as well as the need for Indigenous consent for the approval of any development project affecting native lands. ${ }^{19}$ The ILO Convention contains similar standards, including an obligation on states parties to 'respect the special importance for the cultures and spiritual values of the peoples concerned of their relationship with the lands or territories'. ${ }^{120}$ To secure these rights and values, the Convention declares that Indigenous peoples have the right to 'participate in the use, management and conservation' of their natural resources. Yet, the effectiveness of such lofty standards is debatable. Few states have ratified the ILO Convention, and Australia, Canada, New Zealand and the US have so far shunned it. Although the UN Declaration fares better, with over 140 signatories, it is a softer law standard than the ILO Convention.

International environmental conventions containing provisions on Indigenous peoples may be more useful, given that many of these treaties

\footnotetext{
114 República de Bolivia Constitución Política con Texto Acordado en 1995, art 171.

115 See J Méndez, G O'Donnell and P Pinheiro (eds), The Rule of Law and the Underprivileged in Latin America (University of Notre Dame Press, 1998).

116 International Labour Ogranisation (ILO), Convention No 169 1989, 28 ILM 1382; see further RL Brash, 'An Advocate's Guide to the Convention on Indigenous and Tribal Peoples’ (1990) 15 Oklahoma Law Review 209.

117 UN Doc A/61/L.67, September 7, 2007.

$118 \quad$ Ibid, art 26.

119 Ibid, art 30.

120 ILO Convention 169, above n 116, art 13.
} 
enjoy extensive ratifications. The Convention on Biological Diversity of $1992,{ }^{121}$ ratified by some 190 states, obliges state parties to:

respect, preserve and maintain knowledge, innovations and practices of indigenous and local communities embodying traditional lifestyles relevant for the conservation and sustainable use of biological diversity and promote their wider application with the approval and involvement of the holders of such knowledge, innovations and practices and encourage the equitable sharing of benefits arising from the utilization of such knowledge, innovations and practices. ${ }^{122}$

Still, the protection offered attaches only to 'traditional lifestyles' (reflective of the ecological guardians perspective) and the article dilutes the obligations by relying, in the opening clause (not quoted above), on such dubious qualifications as 'as far as possible and appropriate' and 'subject to its national legislation'. Still, as the following sections show, some national legislation and other legal sources do respect Indigenous traditional hunting and fishing rights.

\section{TERRITORIAL-BASED ENVIRONMENTAL RIGHTS}

Indigenous peoples should enjoy the most extensive opportunities to participate in environmental decisions in relation to those territories that they own and occupy. Whether they hold the land under freehold or Aboriginal title, Indigenous landowners in theory can determine how the land is used or protected. ${ }^{123}$

Yet, for any private property owner, Indigenous or non-Indigenous, in most jurisdictions the Blackstonian notion of absolute, unfettered control over land use is a myth. Modern systems of planning law and environmental regulation have long effectively nationalised rights to development, allowing governments to control even the most seemingly

1992, 31 ILM 818.

Art 8(j).

Curran and M'Gonigle, above n 5, 716. 
trivial activities such as erecting a shed or pruning a tree. ${ }^{124}$ Property rights in Western legal traditions are conceptualised as a bundle of rights, in which development and environmental rights are increasingly the prerogative of governmental authorities. Indigenous property can be similarly regulated. Thus, in Scandinavia, Indigenous territories have been opened to mining, logging and other uses without the consent of, and sometimes even consultation with, the Sámi people. ${ }^{125}$ Usually only where tribal landowners also enjoy a measure of self-governance can they exercise such prerogatives, as occurs to some extent in tribal reservations in the US, as discussed later in this chapter.

Even constitutionally-protected Aboriginal and treaty-based resource rights in Canada are susceptible to land use regulation by the Crown. The Canadian Supreme Court has held that federal regulations ${ }^{126}$ and provincial regulations ${ }^{127}$ may restrict Aboriginal hunting and fishing activities so long as the regulation rests on 'valid legislative objectives' that are compelling and substantial, and the limitation itself is compatible with the Crown's fiduciary duty to First Nations. ${ }^{128}$ In Delgamuukw, ${ }^{129}$ Lamer CJ explained what this could mean in relation to developments on lands under full Aboriginal title:

the development of agriculture, forestry, mining, and hydroelectric power, the general economic development of the interior of British Columbia, protection of the environment or endangered species, the building of infrastructure and the settlement of foreign populations to

See P Booth, 'Nationalising Development Rights: The Feudal Origins of the British Planning System' (2002) 29 Environment and Planning B: Planning and Design 129; JC Nicholas, 'State and Regional Land Use Planning: The Evolving Role of the State' (1999) 73 St Johns University Law Review 1069.

G Nettheim, G Meyers and D Craig, Indigenous Peoples and Governance Structures: A Comparative Analysis of Land and Resource Management Rights (Aboriginal Studies Press, 2002) 219; L Watters, 'Indigenous Peoples and the Environment: Convergence from a Nordic Perspective' (2002) 20 UCLA Journal of Environmental Law and Policy 237.

$126 \quad R v$ Sparrow (1990) 1 SCR 1075.

$127 \quad R v$ Côté (1996) 3 SCR 139.

128 L Dufraimont, 'From Regulation to Recolonization: Justifiable Infringement of Aboriginal Rights at the Supreme Court of Canada' (2000) 58 University of Toronto Faculty Law Review 1.

129 Delgamuukw v British Columbia (1997) 3 SCR 1010. 
support those aims, are the kinds of objectives that are consistent with this purpose and, in principle, can justify the infringement of aboriginal title. ${ }^{130}$

However, the 2007 case of Tsilhqot'in Nation reviewed the test for justification of the infringement of Aboriginal rights. ${ }^{131}$ The Supreme Court of British Columbia held that the province had failed in its obligations to consult with the Tsilhqot'in and that actions taken by the province under its forestry legislation were unjustified infringements of Tsilhqot'in aboriginal rights.

Even more extensive land use control is exercisable by the Crown where such constitutional protections are absent. In Australia, traditional and non-commercial hunting and food-gathering by Indigenous persons are protected under several laws such as the Native Title Act 1993 (incorporating the Mabo judgement of 1992), ${ }^{132}$ and some state- and territory-based land rights legislation such as the Aboriginal Land Rights (Northern Territory) Act $1976 .{ }^{133}$ However, in the wake of the Wik case, ${ }^{134}$ the former Howard government watered down some of the statutory protections to make it easier for governments or companies to use Aboriginal lands for various uses contrary to the wishes of the titleholders. ${ }^{135}$ The Native Title Act does not allow native title owners to veto mining projects on their land; rather, it merely concedes rights to be consulted and to negotiate with the government and mining company. ${ }^{136}$

In some developing countries, such as Papua New Guinea and the Philippines, Indigenous land tenures are widely recognised. ${ }^{137}$ For instance, the Philippines Indigenous Peoples' Rights Act 1997 establishes procedures for confirmation of communal ownership of ancestral land, and some 3 million hectares are now held by Indigenous groups under these

\footnotetext{
$130 \quad$ Ibid, para 165.

[2007] BCSC 1700.

Mabo and Others v Queensland (No 2) (1992) 175 CLR 1.

See RH Bartlett, Native Title in Australia (2nd edn, Lexis Nexis Butterworths, 2004).

Wik Peoples v Queensland (1996) 187 CLR 1.

Native Title Amendment Act 1998 (Cth).

Subdivision $\mathrm{P}$.

RG Crocombe (ed), Land Tenure in the Pacific. (University of the South Pacific, 1994); T van Meijl and F von Benda-Beckmann (eds), Property Rghts and Economic Development: Land and Natural Resources in Southeast Asia and Oceania (Kegan Paul, 1999).
} 
provisions. ${ }^{138}$ The 'rights of ownership' recognised under the Philippine law include the right 'to negotiate the terms and conditions for the exploration of natural resources in the areas for the purpose of ensuring ecological, environmental protection and conservation measures, pursuant to national and customary laws'. ${ }^{139}$ Similarly, in Latin America, some nations have made progress in demarcation and titling of Indigenous lands. ${ }^{140}$ The Amazon's Huaorani people received from the Ecuadorian government some 676,000 hectares of Amazon land in 1990, dedicated as a Huaorani ethnic reserve. ${ }^{141}$ Government agencies and environmental scientists in the region are starting to acknowledge that Indigenous-held land can dovetail with nature conservation goals. ${ }^{142}$

\section{RESOURCE HARVESTING RightS}

Indigenous environmental rights are not necessarily tied to ownership of the land. They may involve usufruct-type rights associated with areas traditionally fished or hunted. For example, 'immemorial' rights of the Sámi people to reindeer herding, hunting and fishing have been recognised by the Norwegian ${ }^{143}$ and Swedish courts. ${ }^{144}$ In the US and Canada, where the following discussion concentrates, such rights have been recognised on the basis of treaties and custom. While harvesting rights are culturally and economically significant to their holders, they do not alone provide a basis for comprehensive environmental management.

\footnotetext{
$138 \quad$ M Colchester, 'Indigenous Peoples and Communal Tenures in Asia', in Land Reform, Land Settlement and Cooperatives (UN Food and Agricultural Organisation, 2004) 28, 38.

139 Section 7.b.

140 R Plant and H Soren, Land Titling and Indigenous Peoples, Sustainable Development Department Technical Papers Series (Inter-American Development Bank, 2001).

141 JE Brady, 'The Huaorani Tribe of Ecuador: A Study in Self-Determination for Indigenous Peoples' (1997) 10 Harvard Human Rights Journal 302.

142 T Walschburger, 'Delimitación y Manejo de Territorios Indígenas Ecológicamente Equilibrados en Áreas de Selva Húmeda Tropical' in M Cárdenas, HD Correa and M Gómez (eds), Derechos Territoriales Indígenas y Ecología (Cerec-Fundación Gaia, 1992) 261.

143 Altevatn Case, L nr 42, nr 8/1966 (1966).

144 Taxed Mountain Case ('Skattefja Ilsma'l'), NJA 1981 s 1 (1981); see further Nettheim, Meyers and Craig, above n 125, 209-35.
} 
In the US, treaties signed by Native American tribes not only affirmed tribal members' rights to hunt and fish on reservation lands, they also sometimes guaranteed them such rights in their traditional harvesting grounds located outside the reservations. ${ }^{145}$ These off-reservation rights have led to intense opposition from state governments and non-Indian hunters and fishers who have sought to make Native Americans subject to state game regulations. The US courts, however, have mostly upheld the off-reservation hunting and fishing rights of Native Americans. In the 1905 case of United States $v$ Winans, even such rights over privately owned land were upheld. ${ }^{146}$

The most intense conflicts over off-reservation harvesting rights have flared in the state of Washington, leading to several judicial rulings on the ambit of tribal fishing rights. In a 1942 case, Tulee $v$ Washington, the court ruled that tribal members could not be forced to purchase fishing licenses because the treaties that their ancestors had signed already reserved the right to fish in the 'usual and accustomed places'. ${ }^{147}$ In Puyallup I, the court ruled that state authorities have the right, pursuant to conservation policy goals, to regulate tribal fishing activities, so long as they do 'not discriminate against the Indians'. ${ }^{148}$ Disputes have also arisen over the apportionment of fish resources between tribal and non-Indian interests; in United States $v$ Washington, ${ }^{149}$ the court determined that the treaty rights guaranteed the Native Americans the right to a certain percentage of the harvestable catch, up to 50 percent. ${ }^{150}$

In Canada, off-reservation hunting and fishing are also recognised. While such entitlements may be based on customary rights independent of a treaty, and have enjoyed constitutional protection since 1982, governments may still regulate such rights in a manner that achieves

145 Even when hunting and fishing rights were not specifically recognised in treaties, the reserved-rights doctrine holds that tribes retain any rights that are not explicitly abrogated by treaty or statute: JV Royster, Native American Natural Resources Law: Cases and Materials (2nd edn, Carolina Academic Press, 2008). 198 US 371, S Ct 662, 49 L Ed 2d 1089 (1905). 315 US 681, 62 S Ct 862, 86 L Ed 1115 (1942). Puyallup Tribe v Department of Game, 391 US 392, 88 S Ct 1725, 20 L Ed 2d 689 (1968).

384 F Supp 312 (WD Wash 1974).

This decision was affirmed by the US Supreme Court in a collateral case: Washington $v$ Washington State Commercial Passenger Fishing Vessel Ass'n 443 US 658, 99 S Ct 3055, 61 L Ed 2d 823 (1979). 
similar arrangements as found in the US. In the seminal Sparrow case of 1990, the Canadian Supreme Court held Aboriginal fishing rights cannot be infringed without justification on account of the government's fiduciary duty to the Aboriginal peoples. ${ }^{151}$ In Van der Peet, in denying that the Aboriginal people in question have fishing rights that extend to commercial sale of fish, the Court ruled that the practices, customs and traditions must have been an integral part of the distinctiveness of their culture prior to colonial contact. ${ }^{152}$ In the Powley case of 2003, the courts also found that the Métis peoples (of mixed Aboriginal and European ancestry) also enjoyed customary rights to hunt wildlife for food. ${ }^{153}$ On the other hand, in 2005 the Canadian Supreme Court, in the cases of Marshall and Bernard, denied that the Mi'kmaq people held Aboriginal or historic treaty rights to $\log$ Crown forests without a permit for commercial gain. ${ }^{154}$

A limitation of Aboriginal harvesting rights in both the US and Canada is that they have not always been interpreted by courts as implying environmental protection of the habitat that supports the wildlife. In order to enjoy Aboriginal harvesting rights there surely must be edible and abundant fish and wildlife populations to support harvesting. Occasionally, courts have recognised implied environmental rights. The British Columbia Court of Appeal in Claxton ruled that environmental degradation posed by a government-licensed marina would impermissibly infringe a treaty right to fish. ${ }^{155}$ The Canadian Supreme Court in Mikisew Cree First Nation recognised that the Aboriginal treaty right to trap and hunt is geographically limited, and it would lose its value without the preservation of the enabling wildlife habitat. ${ }^{156}$ US law also recognises some implied water protection rights for the maintenance of on-reservation

151 Sparrow, above n 126; see further LI Rotman, 'Defining Parameters: Aboriginal Rights, Treaty Rights, and the Sparrow Justificatory Test' (1998) 36 Alberta Law Review 149.

152 (1996) 2 SCR 507. Compare to $R v$ Gladstone (1996) 2 SCR 723, where the court held that Aboriginal defendants have an Aboriginal right to take and sell certain fish species in commercial quantities.

$153 \quad R v$ Powley (2003) 2 SCR 207.

$154 \quad R v$ Marshall; $R$ v Bernard (2005) 2 SCR 220.

$155 \quad$ Saanichton Marina Ltd $v$ Claxton (1989) 57 DLR (4th) 161, 36 BCLR (2d) 79 (CA) (eC).

Mikisew Cree First Nation v Canada (Minister of Canadian Heritage) [2005] SCC 69, paras 2, 45. The Mikisew treaty right to hunt in the national park was threatened by the Crown decision to build a road through the area. 
fishing, based on the United States $v$ Adair and Kittitas Reclamation District $v$ Sunnyside Valley Irrigation District cases. ${ }^{157}$

However, in all of these cases, the traditional harvesting territory of the tribal group was near the environmental damage. For Aboriginal peoples who harvest migratory species, a much larger habitat area used by the animal would need safeguarding. In many other cases, given the interconnectedness of the natural environment, activities occurring afar may indirectly affect fish and wildlife populations within traditional hunting areas. Adequate proof that a proposed activity would cause harm to wildlife and therefore infringe harvesting rights would be a barrier for some Aboriginal groups in such situations.

One solution, as taken in New Zealand, is to insert into general environmental legislation specific provisions to guard Indigenous interests. The Resource Management Act 1991 - the country's principal environmental and land use planning statute - affirms as a matter of 'national importance' the 'relationship of Māori and their culture and traditions with their ancestral lands, waters, sites', ${ }^{158}$ as well as the Māori environmental stewardship principle of 'Kaitiakitanga', 159 to which government decision-makers must have regard when administering the legislation. ${ }^{160}$ The Act has led to municipal planning authorities usually consulting with Māori iwi when considering resource development applications. ${ }^{161}$

Indigenous harvesting rights are also affirmed in some international environmental conventions, which signatory states must respect. Under the International Convention for the Regulation of Whaling, ${ }^{162}$ in 1989 the International Whaling Commission approved a small Aboriginal subsistence whaling quota. ${ }^{163}$ The prohibition on hunting

$157 \quad$ United States v Adair, 478 F Supp 336 (D Or 1979); United States v Adair, 187 F Supp 2d 1273 (D Or 2002); Kittitas Reclamation District v Sunnyside Valley Irrigation District, 763 F 2d 1032 (9th Cir 1985).

$158 \quad$ Resource Management Act 1991, s 6(e).

$159 \quad$ Ibid, s 7(a).

160 See generally P Beverley, 'The Mechanisms for the Protection of Māori Interests Under Part II of the Resource Management Act 1991' (1998) 2 New Zealand Journal of Environmental Law 121.

161 Ministry for the Environment (MfE), Case Law on Tangata Whenua Consultation (MfE, 1999). 1946, 161 UNTS 72.

The Commission has established a sub-committee to deal with aboriginal subsistence whaling: see NC Doubleday, 'Aboriginal Subsistence Whaling: The 
polar bears imposed by the Agreement on Polar Bears of 1973 does not apply in relation to hunting 'by local people when using traditional methods in the exercise of their traditional rights'. ${ }^{164}$ The Convention on Conservation of North Pacific Fur Seals of 1976 exempts Indigenous groups inhabiting certain coastal areas from the ban on sealing when not using specified modern technologies. ${ }^{165}$ Limiting the exercise of such rights to traditional hunting methods presumably aims to limit the size of the harvest. Such restrictions, however, overlook that the most important mechanism to limit harvesting is the purpose (ie, subsistence living) rather its means (eg, modern weaponry). ${ }^{166}$

In the future, intellectual property (IP) law appears likely to provide another basis for some Indigenous environmental rights. ${ }^{167}$ This trend is best illustrated by the far-reaching claim filed by Māori groups to the Waitangi Tribunal seeking control of knowledge-based uses of New Zealand's entire panoply of native flora and fauna. ${ }^{168}$ Reliance on IP law, in addition to territorial-based rights, to protect Indigenous interests in the environment has arisen principally because of the growing commercial pressures to exploit Indigenous knowledge and culture in the fields of biotechnology, agriculture and tourism. ${ }^{169}$

Indigenous peoples remain vigilant about such uses without their consent. The UN Declaration on the Rights of Indigenous Peoples also affirmed their right

to maintain, control, protect and develop their cultural heritage, traditional knowledge and traditional cultural expressions, as well as the manifestations of their sciences,

Right of Inuit to Hunt Whales and Implications for International Environmental Law' (1989) 17 Denver Journal of International Law and Policy 373. Art III(d), Agreement on Polar Bears 1973, 13 ILM 13, Art VII, Convention on Conservation of North Pacific Fur Seals 1976, 27 UST 3371.

Indigenous Peoples and Sustainability, above n 15, 64-65.

See eg, T Janke, Our Culture, Our Future: Proposals for the Recognition and Protection of Indigenous Cultural and Intellectual Property (Michael Frankel, 1997).

Waitangi Tribunal, at www.waitangi-tribunal.govt.nz.

F Yamin and D Possey, 'Indigenous Peoples, Biotechnology and Intellectual Property Rights' (1997) 2 RECIEL 141; DA Cleveland and SC Murray, 'The World's Crop Genetic Resources and the Rights of Indigenous Farmers' (1997) 38 Current Anthropology 477, 483-85. 
technologies and cultures, including human and genetic resources, seeds, medicines, knowledge of the properties of fauna and flora, ... ${ }^{170}$

However, to implement such standards within mainstream IP law is difficult, as copyrights, trademarks and patents are not easily adapted to Indigenous knowledge. ${ }^{171}$ They are designed to promote innovation and commercialisation of knowledge, whereas Indigenous communities tend to be more interested in preserving the integrity of existing traditional knowledge. The IP law requirements of authorship and novelty also pose difficulties where traditional knowledge has evolved gradually from generation to generation and is owned collectively. Currently, there are few international or national legal instruments that create specific IP standards tailored to Indigenous knowledge or cultural practices.

\section{E. INDIGENOUS LAND USE GOVERNANCE}

Logically, environmental governance should coincide with Indigenous interests most closely in those areas over which Indigenous communities exercise self-governance. Their quest for self-governance, as discussed in Shin Imai's chapter in this book, has often centred on resource management. In this context, self-governance could mean an Indigenous group asserting jurisdiction over wildlife harvesting, mining, forestry, water extraction and other conceivable land uses in a manner compatible with community preferences. The quality of self-governance depends on many factors, including whether Indigenous authorities have community support, adequate financial resources and technical expertise, as well as the size of the land mass governed, and the extent of jurisdiction over the activities of non-Aboriginal actors.

In the US, with some of the most comprehensive systems of tribal governance such as on the Navaho reservation, courts have long recognised Native American tribes as independent, distinct political entities retaining inherent sovereign powers to the extent these have not

\footnotetext{
$170 \quad$ Art 31(1)

171 S Patel, 'Can the Intellectual Property Rights System Serve the Interests of Indigenous Knowledge?' in S Brush and D Stabinsky (eds), Valuing Local Knowledge (Island Press, 1996).
} 
been ceded to or taken away by Congress. ${ }^{172}$ Thus, tribes enjoy full equitable ownership of timber and mineral resources located on tribal reservations, and can regulate hunting and fishing on their reservations. Importantly, in 2003 the US court ruled that the Sokaogon Chippewa in Wisconsin have the right to regulate water quality on their reservation and to set water quality standards higher than those promulgated by state authorities. ${ }^{173}$ While tribes may also possess off-reservation fishing and hunting rights, as noted earlier, these rights would not ordinarily carry concomitant governance authority. ${ }^{174}$

Apart from self-governance powers derived from their inherent sovereignty, tribes may also hold delegated legislative powers. In 1984 the US Environmental Protection Agency (EPA) adopted a Federal Indian Policy which recognised tribal governments as the appropriate sovereign for setting environmental standards, issuing permits and managing environmental programs within reservation boundaries. ${ }^{175}$ Since then, numerous federal environmental statutes have authorised delegation of regulatory authority to tribes, including: the Clean Water Act, the Clean Air Act, and the Surface Mining Control and Reclamation Act, among many examples. Few tribes have been able to take advantage of such powers without additional federal funds and technical support. ${ }^{176}$

A setback for tribal governance has arisen from some US court decisions denying tribes the authority to regulate hunting and fishing on non-Indian fee simple lands within reservation boundaries, ${ }^{177}$ or to regulate non-Indian resource use within reservations. ${ }^{178}$ These limitations can severely undermine tribes' ability to provide comprehensive land management schemes in reservations containing substantial non-Indian parcels, as many do.

\footnotetext{
172 See Johnson $v$ M'Intosh, 21 US (8 Wheat) 543, 572-88 (1823).

173 State of Wisconsin v Environmental Protection Agency, et al, 266 F3d 741 (7th Cir 2001).

174 Nettheim, Meyers and Craig, above n 125, 40.

175 WD Ruckelshaus, EPA Policy for the Administration of Environmental Programs on Indian Reservations (American Indian Environmental Office, 1984).

176 JA Milford, 'Tribal Authority Under the Clean Air Act: How Is It Working?' (2004) 44 Natural Resources Journal 213.

$177 \quad$ Montana $v$ United States, 45 US 544, 566 (1981).

$178 \quad$ United States v Anderson, 736 F 2d 1358, 1366 (9th Cir 1984).
} 
These jurisdictional lacunae are curious omissions, for even under Canada's much-loathed Indian Act 1876, bands' by-law powers apply to everyone within the reservation. On the other hand, the Indian Act gives bands only rudimentary land use powers, such as management of stray dogs and removal of weeds. ${ }^{179}$ First Nations and the Canadian government negotiated a Framework Agreement in 1996 to provide an alternative land management regime on reservations. The resulting First Nations Land Management Act 1999 gives bands the choice to opt into a different selfgovernance regime over their reserve land. ${ }^{180}$ As of July 2008, at least 35 First Nations had committed to this process, which involves the drafting of a new land management code for each community and negotiation of an individual agreement with Indian Affairs and Northern Development. The land management codes drafted to date, such as the Scugog Island First Nation Land Management Code, tend to resemble municipal planning codes setting out procedural standards rather than substantive environmental or land use policy goals. ${ }^{181}$

Although Indigenous communities may enjoy significant control over natural resources on designated reserves, the small size of many reserves make long-term, sustainable management approaches impractical. According to the 1996 report of the Royal Commission on Aboriginal Peoples, nearly 80 per cent of the some 600 First Nations reservations in Canada are less than 500 hectares in size. ${ }^{182}$ These reservations are probably not viable for comprehensive ecosystem-wide management. For example, in forestry management, many reservations have been found to be too small to allow for traditional rotation methods of log harvesting. ${ }^{183}$ A further problem is that natural resources on First Nation lands may be harmed by third party pollution, emanating from distant places beyond Indigenous control. In the case involving ICI Canada, the First Nation was unable to prevent the company from discharging pollutants into a river that ultimately flowed through their reservation. ${ }^{184}$

\footnotetext{
$179 \quad$ See ss $18,57,58,73$.

180 See T Isaac, 'First Nations Land Management Act and Third Party Interests' (2005) 42 Alberta Law Review 1047.

See www.fafnlm.com/content/en/LandCodes.html.

Royal Commission on Aboriginal Peoples, Report (Minister of Supply and Services, Canada, 1996) Part 2(2), 810-11.

Curran and M'Gonigle, above $\mathrm{n} 5$.

Walpole Island First Nation v Ontario [1997] OJ No 3768, 35 OR (3d) 113 (Ct J (Gen Div)).
} 
The 2000 Nisga'a Final Agreement in British Columbia is a rare example of a framework for an Aboriginal Nation to exercise substantial environmental self-governance over a large area. ${ }^{185}$ Covering some 2,000 $\mathrm{km}^{2}$ of Nisga'a lands, well as some adjacent Crown lands, the treaty gave the Nisga'a Lisims Government a primary role in the environmental assessment and protection of project proposals on Nisga'a lands. ${ }^{186}$ While federal or provincial law will prevail whenever there is a conflict with Nisga'a environmental laws, the Nisga'a Agreement also provides a key safeguard: '[n]o Party should relax its environmental standards in the Nass Area for the purpose of providing an encouragement to the establishment, acquisition, expansion, or retention of an investment' ${ }^{187}$ By contrast, the other comprehensive land settlements negotiated in Canada in recent years have tended to provide for resource management institutions jointly controlled by Indigenous and non-Indigenous interests, rather than Aboriginal self-governance, as the following section explains.

\section{F. JOINT RESOURCE MANAGEMENT}

Indigenous communities may also participate in environmental decisionmaking through cross-cultural institutions that allow Aboriginal and nonAboriginal stakeholders to work collaboratively in managing wildlife, forests, water and other natural resources.

Perhaps the leading example is Canada's Comprehensive Land Claims Process (CLCP), which has led to nearly twenty major settlements since it began in the mid-1970s. ${ }^{188}$ First Nations and the federal and other governments have negotiated complex agereements for financial compensation, co-management of Aboriginal lands, wildlife management and regional development. ${ }^{189}$ Most have involved areas in northern Canada where Aboriginal or Inuit lands were never historically ceded to

185 D Sanders, 'We Intend to Live Here Forever: A Primer on the Nisga'a Treaty' (1999) 33 University of British Columbia Law Review 103.

$186 \quad$ Nisga'a Final Agreement (2000) chapter 10.

$187 \quad$ Ibid, para 18.

188 See Nettheim, Meyers and Craig, above n 125; Richardson, Craig and Boer, above $\mathrm{n} \mathrm{111.} \mathrm{The} \mathrm{Canadian} \mathrm{CLCP,} \mathrm{however,} \mathrm{was} \mathrm{inspired} \mathrm{by} \mathrm{the} \mathrm{earlier} \mathrm{Alaska}$ Native Claims Settlement Act, Pub L No 92-203, 85 Stat 339 (1971).

189 Indian and Northern Affairs Canada (INAC), Comprehensive Claims Policy and Status of Claims (INAC, 2003). 
the Crown. Negotiation of the CLCP agreements has often been precipitated by development pressures; the Inuvialuit Agreement of 1984 was negotiated against the back-drop of the discovery of oil and gas deposits in the region. ${ }^{190}$ The Nisga'a Agreement was also shaped partly by disputes over deforestation and control of British Columbia's lucrative salmon fishery. ${ }^{191}$

Each CLCP agreement creates specific institutions for environmental governance that are typically managed jointly by Indigenous and governmental representatives. The Nunavut Agreement of 1993 contains perhaps the most extensive array of governance institutions, including: a Nunavut Wildlife Management Board; a Nunavut Impact Review Board to screen project proposals and to monitor projects that do proceed; a Nunavut Planning Commission to oversee general land use planning; a Nunavut Water Board; and a Surface Rights Tribunal. ${ }^{192}$ In each institution, the federal or territorial government representatives have an overriding obligation to ensure sustainable utilisation and resource conservation, but they must also act in accordance with basic constitutional principles on Aboriginal rights. ${ }^{193}$ Thus, in Kadlak $v$ Nunavut the court considered the legality of a Minister's decision to overrule a recommendation of the Nunavut Wildlife Management Board to allow traditional hunting of polar bears. ${ }^{194}$ The court viewed the decision of the Minister as a prima facie infringement on an Aboriginal right that could not be justified under the Sparrow test, and the matter was referred to the Minister for reconsideration. ${ }^{195}$

While the Canadian examples of cross-cultural resource management may be faulted for often assigning Indigenous parties only a minority voice, they compare favourably to models in other jurisdictions.

190 AJ Black, 'Legal Principles Surrounding the New Canadian and American Arctic Energy Debate' (2002) 23 Energy Law Journal 81, 83.

191 DE Stokes, 'Modern Treaty Making with First Nations in British Columbia' (2000) 8 Waikato Law Review 117, 122.

192 Agreement Between the Inuit of the Nunavut Settlement Area and Her Majesty The Queen in Right of Canada, May 25, 1993; see further C Marecic, 'Nunavut Territory: Aboriginal Governing in the Canadian Regime of Governance' in L Watters (ed), Indigenous Peoples, Environment and Law (Carolina Academic Press, 2004) 205. 
In Australia, by contrast, governments have tended to limit the Aboriginal voice to various advisory committees and consultation mechanisms. ${ }^{196}$ Such arrangements have been introduced under the Torres Strait Fisheries Act 1984 and the Environment Protection and Biodiversity Conservation Act 1999, for instance. ${ }^{197}$

The joint management of protected areas in Australia provides a more genuine example of cross-cultural resource management. ${ }^{198}$ The Kakadu and Uluru national parks in the Northern Territory are among the most comprehensive and successful examples of joint management. ${ }^{199}$ They each provide for Aboriginal ownership and lease-back of the land to the government conservation agency, an Aboriginal majority on the board of park management, and financial payments to the traditional owners. Jointly managed national parks have also led to advances in cross-cultural education, training and employment for local Indigenous communities to share in the economic benefits of parks. There are also numerous examples of less formal partnerships for environmental management in Australia. These include the Kowanyama community strategy for joint management of fisheries resources in Queensland's Mitchell River, and the natural and cultural resource management undertaken by the Dhimurru Land Management Aboriginal Corporation in Arnhem Land. ${ }^{200}$

Another distinctive feature of the Australian approach to Indigenous participation in environmental governance is the extensive use of contractual arrangements between Aboriginal organisations, public agencies and developers relating to land and cultural heritage management. ${ }^{201}$ One example is the partnership agreements negotiated

$196 \quad$ Nettheim, Meyers and Craig, above n 125, 393.

197 D Craig, Aboriginal and Torres Strait Islander Involvement in Bioregional Planning: Requirements and Opportunities under International and National

198 Law and Policy (Department of Environment, Sport and Territories, 1996). S Woenne-Green, et al, Competing Interests: Aboriginal Participation in National Parks and Conservation Reserves in Australia (Australian Conservation Foundation, 1994).

T DeLacy and B Lawson, 'The Uluru-Kakadu Model: Joint Management of Aboriginal-Owned National Parks in Australia' in S Stevens (ed), Conservation through Cultural Survival: Indigenous Peoples and Protected Areas (Island Press, 1997).

Nettheim, Meyers and Craig, above n 125, 384-85.

See E Young et al, Caring for Country: Aborigines and land management (Australian National Parks and Wildlife Service, 1991); H Jarieth and D Craig, 
pursuant to the Indigenous Protected Areas (IPAs) program under the Natural Heritage Trust of Australia Act 1997, providing for co-operative management of terrestrial and marine areas as protected sites. Another example is the Indigenous Land Use Agreements (ILUAs) negotiated under the Native Title Act, allowing native title claimants to enter into resource management arrangements, such as for biodiversity conservation, in territories under claim. ${ }^{202}$

Negotiated agreements have also been used in New Zealand for joint resource management. The most important settlement is the 1989 and 1992 'Sealords' agreements by which the Crown agreed to transfer a large proportion of the nation's commercial fisheries quota to the newly created Treaty of Waitangi Fisheries Commission to manage on behalf of all Māori, and to provide funding to enable the Commission to purchase the Sealords fishing company. ${ }^{203}$ In return, Māori agreed that the settlement would discharge and extinguish all of their commercial fishing rights and claims against the Crown. ${ }^{204}$ There have been other negotiated settlements for the return of Māori tribal lands, financial compensation and comanagement of natural resources, although not as comprehensive as the Canadian examples. ${ }^{205}$

\section{G. ENVIRONMENTAL GOVERNANCE BEYOND THE STATE}

Another governance trend is the growing influence of the corporate sector, including in the areas of environmental policy and Indigenous peoples. Corporate influence in governance has mushroomed in the wake of policy shifts in many countries, particularly in the Anglo-American sphere, to

'Governance Structures for "Country" on and off Native Title Lands' in Nettheim, Meyers, Craig, above n 125.

D Craig, 'Native Title and Environmental Planning; Indigenous Land Use Agreements' (2000) 17 Environmental and Planning Law Journal 440.

HK Guth, 'Dividing the Catch: Natural Resource Reparations to Indigenous Peoples - Examining the Māori Fisheries Settlement' (2001) 24 Hawaii Law Review 179.

The customary taking of seafood for subsistence needs is also recognised and preserved in government fisheries regulations: Fisheries (Amatuer Fishing) Regulations, cl 27.

Eg, the Tainui and Ngai Tahu settlements: Nettheim, Meyers and Craig, above $\mathrm{n}$ $125,144$. 
reduce the regulatory role of states while ceding greater responsibilities to markets and private sector institutions. ${ }^{206}$ The resulting growth of corporate self-regulation is reflected in the plethora of private sector codes of conduct and voluntary standards, which typically emphasise procedural rather than normative standards. ${ }^{207}$ Procedural standards, such as for public disclosure, consultation and reporting, may make stakeholders (eg, nongovernmental organisations, local communities and Indigenous peoples) more informed of corporate behaviour, promote a dialogue with companies and enable stakeholders to apply pressure for change.

A paradigmatic example of such process standards is the Equator Principles, designed for the financial sector. Through the long-standing movement for socially responsible investment, the financial sector is under mounting pressure from many stakeholders to promote environmentally sustainable development and social justice. ${ }^{208}$ Socially responsible investors began to acknowledge Indigenous rights in the 1980s, following the lead set by the World Bank and other multilateral lenders that pioneered policies for the special treatment of tribal peoples in development projects. $^{209}$ Investors were not principally driven by any ethical belief in the sanctity of Indigenous rights or interests. Rather, they saw a business case for respecting Indigenous interests; the World Resources Institute, for instance, argued that financiers and developers should seek the 'free and informed consent' of affected Indigenous and other local communities if they wish to avoid costly protests and resistance to their economic plans. ${ }^{210}$

206 See C Scott, 'Regulation in the Age of Governance: The Rise of the Post Regulatory State', in J Jordana and D Levi-Faur (eds), The Politics of Regulation: Institutions and Regulatory Reforms for the Age of Governance (Edward Elgar, 2004) 145.

207 See B Krumsiek, 'Voluntary Codes of Conduct for Multinational Corporations: Promises and Challenges' (2004) 109 Business and Society Review 503; D Leipziger, The Corporate Responsibility Code Book (Greenleaf Publishing, 2003).

208 R Sparkes, 'A Historical Perspective on the Growth of Socially Responsible Investment' in R Sullivan and C Mackenzie (eds), Responsible Investment (Greenleaf Publishing, 2006) 39. GA Sarfaty, 'The World Bank and the Internalization of Indigenous Rights Norms' (2005) 114 Yale Law Journal 1791.

210 S Herz, A Vina and A Sohn, Development without Conflict: The Business Case for Community Consent (World Resources Institute, 2007). 
These considerations weighed on the international banking community when it formulated the Equator Principles (EPs). The Principles, which were drafted in 2003, provide a voluntary code of conduct for responsible project financing. ${ }^{211}$ The EPs are based on the World Bank's International Finance Corporation (IFC) standards, the Bank's private sector lending arm. Lenders that sign the EPs agree to implement measures to minimise the social and environmental harm of financed infrastructure projects (eg, dams, highways and mines), such as by following procedures for undertaking environmental and social impact studies before disbursing money, and consulting with affected local communities. $^{212}$

The EPs touch briefly on Indigenous peoples specifically. A bank must ensure that its borrower formulates an 'Indigenous Peoples Development Plan' in accordance with the IFC standards. They provide, in part:

[w]hen avoidance [of adverse impacts] is not feasible, the client will minimize, mitigate or compensate for these impacts in a culturally appropriate manner. The client's proposed action will be developed with the informed participation of affected Indigenous Peoples and contained in a time-bound plan, such as an Indigenous Peoples Development Plan. ${ }^{213}$

The EPs do not, however, require borrowers to obtain the free, prior and informed consent of affected Indigenous communities. The lesser standard of 'consultation' does not necessarily require developers to respond to and address their advice or concerns.

Of the approximately 60 banks that had signed the EPs as of mid2008, few have drafted policies that explicitly address Indigenous peoples. JPMorganChase, with perhaps the most comprehensive policy, commits itself to finance projects only where: free, prior informed consultation using customary institutions results in support of the project by the affected Indigenous people; they have been fully informed about the

\footnotetext{
211 See www.equator-principles.com.

212 T O'Riordan, 'Converting the Equator Principles to Equator Stewardship' (2005) 47(4) Environment 1.

$213 \quad$ IFC, Performance Standard 7: Indigenous Peoples (IFC, 2006) cl 7.
} 
project; they have access to a grievance mechanism; and major Indigenous land claims have been appropriately addressed. ${ }^{214}$ While the policies of JPMorganChase fall short of best practice, they are comparable to governmental policies.

Apart from such procedural standards, occasionally the private sector commits to more substantial standards in its dealings with Indigenous and other local stakeholders. One example used in Canada is formal agreements negotiated between developers and communities. While the Supreme Court of Canada ruled in Haida Nation v British Columbia (Minister of Forests) that resource developers do not owe an independent duty to consult with First Nations, a duty of the Crown that cannot be delegated, some Canadian companies have been acting independently to consult with and reach accommodations with Indigenous resource owners. ${ }^{215}$ One mechanism is 'impact and benefit' agreements (IBAs).

Used particularly in Canada's resource economy, IBAs are typically negotiated between resource-sector corporations, Indigenous communities and sometimes governments as well, to alleviate various adverse socio-economic and environmental impacts that can arise from resource development. ${ }^{216}$ IBAs operate on a project basis and include provisions covering employment, training, profit sharing, compensation, and cultural and environmental protection. Environmental provisions can include additional impact assessments and environmental monitoring. ${ }^{217}$ IBAs do not take the place of official regulation, but may supplement it with additional measures to accommodate the concerns of affected local communities. ${ }^{218}$ One limitation of IBAs as used in Canada is their confidentiality; this restricts public access, and therefore does not allow

\footnotetext{
214 JPMorganChase, 'Environmental Policy', s 4; at www.jpmorganchase.com.

215 (2004) 3 SCR 511.

216 SA Kennett, A Guide to Impact and Benefits Agreements (Canadian Institute of Resources Law, 1999); I Sosa and K Keenan, Impact Benefit Agreements between Aboriginal Communities and Mining Companies (Canadian Environmental Law Association, 2001).

217 K O'Reilly, 'Impact and Benefit Agreements: Tools for Sustainable Development?' (2000) 25(4) Northern Perspectives 1.

218 S Gogal, R Riegert and J Jamieson, 'Aboriginal Impact and Benefit Agreements: Practical Considerations’ (2005) 43 Alberta Law Review 129.
} 
parties entering IBA negotiations to be aware of useful precedents and learn from previous negotiations. ${ }^{219}$

\section{CONCLUSIONS}

Indigenous peoples' ties to environmental governance have been shaped by specific legal rights, as well as academic and policy debates about the relative value of Indigenous knowledge and customs to modern environmental management. It is too simplistic, however, to conclude that more Indigenous control will resolve both their desires for selfdetermination and ensure sustainable use of the environment. Even where Indigenous institutions have remained relatively intact, evidence from the South Pacific, for instance, suggests that the maintenance of customary land tenure systems and tribal authorities has not prevented significant environmental decline. ${ }^{220}$

The purpose of this chapter is not to provide answers to these challenges, but rather to illuminate more fully the complex discourse about Indigenous environmental values and practices, and the governance tools availed to give voice and authority to Indigenous peoples. Yet by understanding these two issues, we should be better placed to evaluate appropriate reforms.

We should be mindful not to assume that there is an inevitable path to reform. While the trend in most jurisdictions has been for more Indigenous voice and authority in environmental governance, setbacks have occurred. Some courts have become less receptive to or ambivalent about Indigenous claims. The US Supreme Court has been 'backtracking on Indian sovereignty', ${ }^{221}$ as evident in Nevada $v$ Hicks. $^{222}$ Tribal

\footnotetext{
$219 \quad$ Kennett, above n 216, 2.

220 DD Paulson, 'Understanding Tropical Deforestation: The Case of Western Samoa’ (1994) 21 Environmental Conservation 326, 329.

$221 \mathrm{P}$ McHugh, Aboriginal Scoieties and the Common Law (Oxford University Press, 2005) 330. Although there were exceptions to this trend, notably California v Cabazon Band, 480 US 202 (1987) (concerning the rights of Indian tribes to operate gaming facilities on Indian reservations), and US v Lara, 541 US 193 (2004) (affirming Congressional power under the constitution to recognise inherent criminal jurisdiction of tribal authorities over non-member Indians).
} 
governments have seen their jurisdiction chipped away. ${ }^{223}$ In Canada, after the ground-breaking Sparrow decision, the Supreme Court retreated somewhat in its judgements in Van der Peet ${ }^{224}$ and Pamajewon. ${ }^{225}$ In Australia, the euphoria of Mabo has abated, because of rulings like Yorta Yorta $^{226}$ that held native title claimants must prove continuous acknowledgement and observance of traditional laws and customs in relation to land. Even when courts favour Indigenous claims, such as the crucial decision of the New Zealand Court of Appeal on Māori rights to the foreshore and seabed, ${ }^{227}$ governments have intervened to extinguish Indigenous rights given sufficient economic and political stakes. The New Zealand government did so with the Foreshore and Seabed Act 2004, as explained further in Jacinta Ruru's chapter.

Enduring measures to safeguard Indigenous environmental practices - and thereby their distinctive cultures - are unlikely to be found if the Aboriginal stake is defined narrowly in terms of mere usufruct rights to harvest plants and animals. Even full territorial rights and Indigenous self-government are likely to be insufficient where the land mass is small and there are no rights to influence environmental decisions on a regional or higher scale. Environmentally threatening processes from afar can undermine even the most robust local resource management regimes. In a global economy, the sustainability of Indigenous livelihoods will increasingly be shaped by factors quite distant from Indigenous homelands. Global warming is the gravest threat, while also being the environmental challenge most beyond Indigenous control. Traditional governance approaches that emphasise Indigenous autonomy and selfcontrol will not work very well in the face of such looming disasters.

What could help? The Inuit of the Arctic regions have submitted a petition to the Inter-American Commission on Human Rights seeking

\footnotetext{
222533 US 353 (2001). In this case the Supreme Court held that state officers could enter an Indian reservation uninvited to investigate or prosecute an offreservation violation of state law. It further held that tribal courts are not empowered to hear civil rights cases under federal law because they are not courts of general jurisdiction.

223 See D Luckerman, 'Sovereignty, Jurisdiction, and Environmental Primacy on Tribal Lands' (2003) 37 New England Law Review 635.

$R v$ Van der Peet (1996) 2 SCR 507.

$R v$ Pamajewon (1996) 2 SCR 821.

Yorta Yorta Aboriginal Community v Victoria [2002] HCA 58.

Ngati Apa v Attorney-General (2003) 3 NZLR 643.
} 
remedies from the US for its contribution to global warming. ${ }^{228}$ While their petition may help to build recognition of an international human right to maintain cultural traditions, reform must also address mechanisms by which Indigenous communities can collaborate with management institutions at other levels of economic policy-making and development planning. If Indigenous livelihoods that respect the environment are to be sustained, an Indigenous voice in local environmental governance is not enough - it must also be heard in the institutions that shape the global economy, trade, finance and other fundamental causes of environmental pressure.

228 Petition to the Inter American Commission on Human Rights Seeking Relief from Violations Resulting from Global Warming Caused by Acts and Omissions of the United States (December 7, 2005). 